\title{
Prediction of reservoir sand in Miocene deltaic deposits in Denmark based on high-resolution seismic data
}

\author{
Erik S. Rasmussen, Thomas Vangkilde-Pedersen and Peter Scharling
}

Intense investigations of deep aquifers in Jylland, western Denmark, during the last seven years have resulted in detailed mapping of Miocene sand-rich deposits laid down in fluvial channels, delta lobes, shoreface and spit complexes (Fig. 1; Rasmussen 2004). Detailed sedimentological and palynological studies of outcrops and cores, and interpretation of high-resolution seismic data, have resulted in a well-founded sequence-stratigraphic and lithostratigraphic scheme (Fig. 1) suitable for prediction of the distribution of sand.

The Miocene succession onshore Denmark is divided into three sand-rich deltaic units: the Ribe and Bastrup sands and the Odderup Formation (Fig. 2). Prodeltaic clayey deposits of the Vejle Fjord and Arnum Formations interfinger with the sand-rich deposits. Most of the middle and upper Miocene in Denmark is composed of clayey sediments referred to the Hodde and Gram Formations (Fig. 2).

This paper presents examples of seismic reflection patterns that have proved to correlate with sand-rich deposits from lower Miocene deltaic deposits and that could be applied in future exploration for aquifers and as analogues for oil- and gas-bearing sands in wave-dominated deltas.

\section{Geology}

During the Early Miocene, the eastern North Sea Basin was filled by siliciclastic sediments sourced from the Fennoscandian Shield. The sediment supply was high due to tectonic uplift of the Fennoscandian Shield (Ziegler 1990; Rasmussen 2004). The North Sea was located in the highlatitude belt of westerly winds, which resulted in a long fetch, and the tidal range is interpreted to be micro- to meso-tidal. Regressions and transgressions during the Early Miocene were strongly controlled by eustatic sea-level changes (Friis et al. 1998; Rasmussen 2004; Rasmussen \& Dybkjær 2005).

During the early Miocene, two phases of shoreline progradation occurred. Sand deposited adjacent to the delta mouth or in association with topographic highs was immediately redistributed and deposited either as spit complexes or as barrier islands in the down-drift areas of delta lobes. These sandrich successions are commonly around $20 \mathrm{~m}$ thick; however, delta lobes prograding into topographic lows, i.e. deep water, are characterised by up to $70 \mathrm{~m}$ thick successions of clean sand. The delta front sediments were deposited either as mass-flow sediments or current-derived deposits. During sealevel fall, incision of the delta plain took place. These incised valleys were successively filled with thick, sand-rich fluvial deposits during the succeeding sea-level rise.

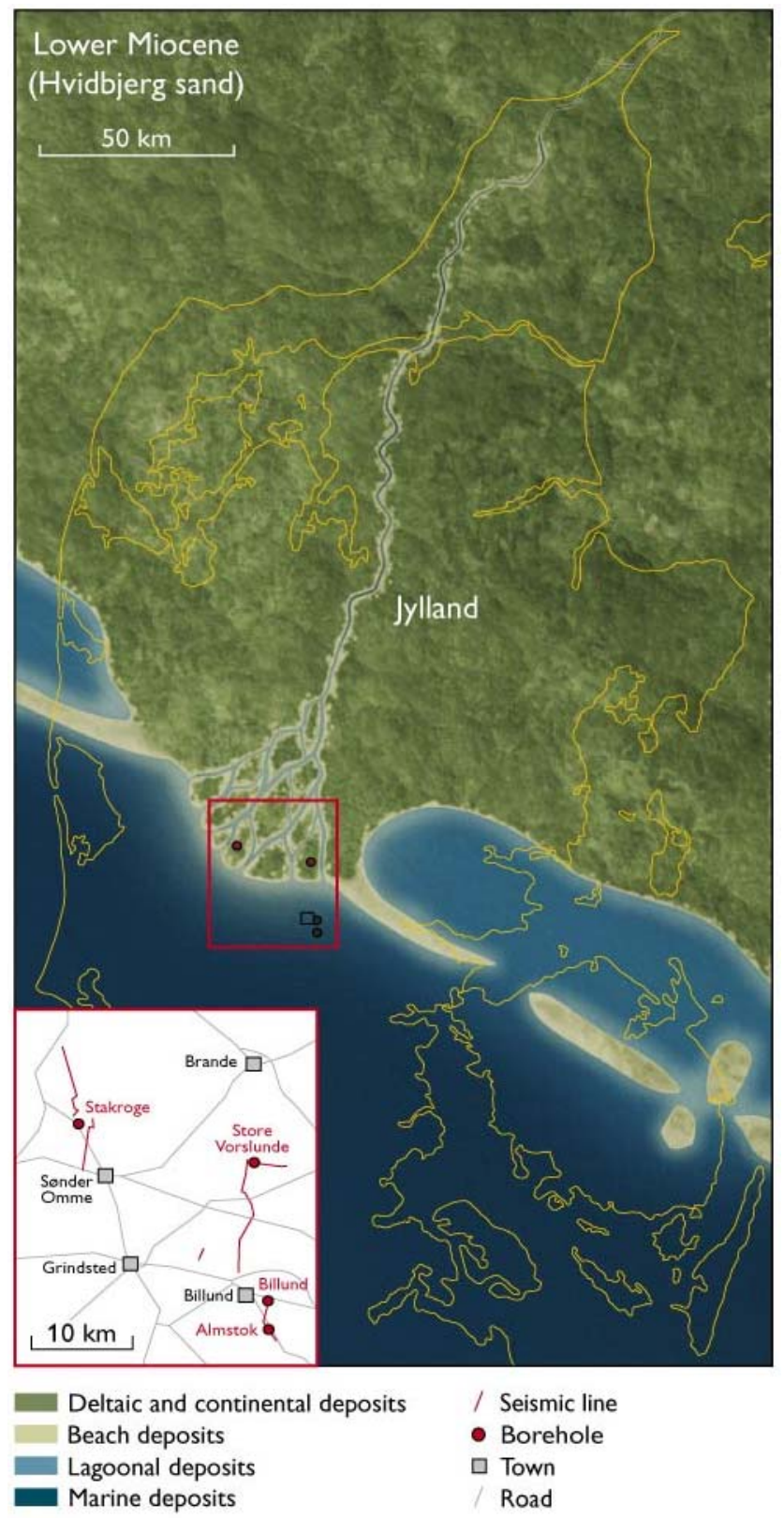

Fig. 1. Map of Jylland showing distribution of Lower Miocene environments (from Rasmussen 2004). Insert map shows position of seismic sections and boreholes used in this study. 


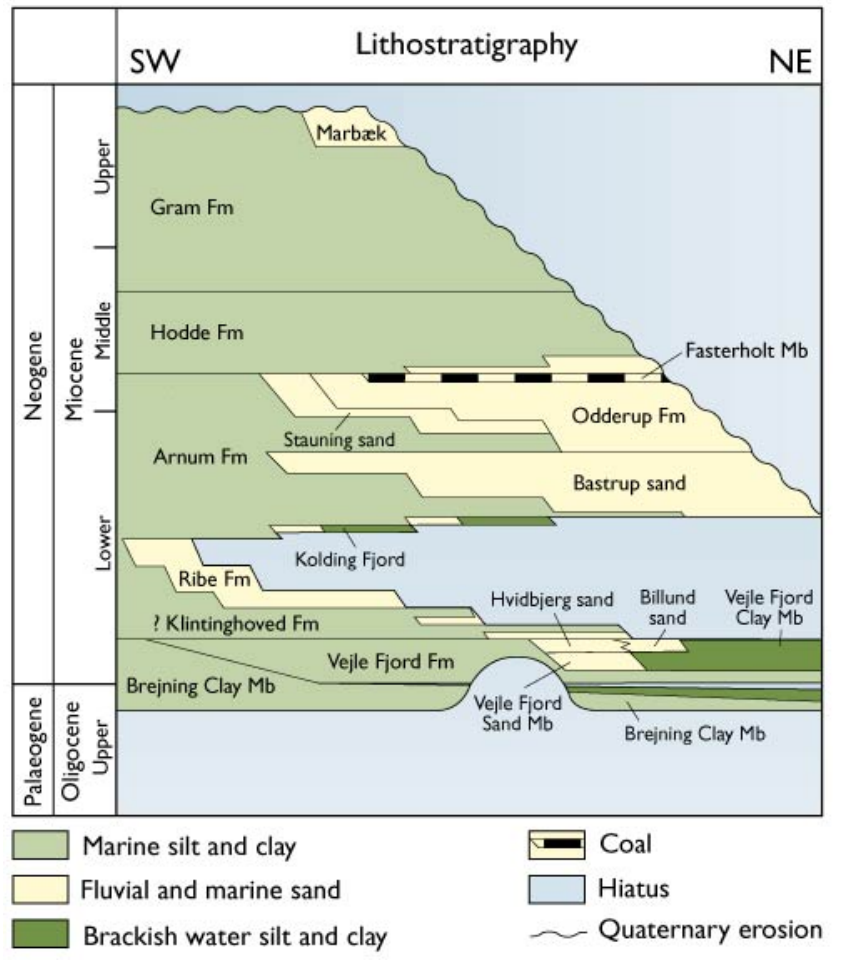

Fig. 2. Lithostratigraphy of the Danish Miocene sediments (modified from Rasmussen 2004)

\section{Seismic data acquisition}

Mapping of aquifers in Denmark has previously been dominated by electric and electromagnetic methods, as the high cost of conventional, shallow, onshore reflection seismic surveys was a factor that limited its use. Recently, however, the technique of landstreamer high-resolution seismic data has provided considerable savings of manpower and increased productivity compared to using traditionally planted geophones and cable lay-outs. The mapping of deeper units is also possible now. The landstreamer technique also facilitates short geophone spacing and differential spacing of geophones along the spread without increasing time- or manpower consumption.

The use of landstreamers for acquisition of shallow seismic data has increased throughout the world in recent years. The landstreamers are commonly used together with relatively weak sources such as a pipegun or sledgehammer (e.g. van der Veen \& Green 1998; van der Veen et al. 2001) resulting in a relatively limited penetration depth (typically a few hundred metres). Since the year 2000, more than $1000 \mathrm{~km}$ of highresolution seismic data have been acquired to map deep aquifers in Denmark. The acquisition setup used has included high-frequency seismic vibrators (3.5 $\mathrm{T}$ and $6.5 \mathrm{~T}$ ) as the energy source. Under normal conditions the landstreamer setup has provided very high data quality with reflections from $c$. 20-50 m down to more than $1 \mathrm{~km}$ with a vertical resolution of 5-10 $\mathrm{m}$. The coverage, especially in the central and western parts of Jylland, provides unique opportunities for interpretation and correlation.

The design of the seismic landstreamers has developed from a $150 \mathrm{~m}, 60$-channel streamer with $2.5 \mathrm{~m}$ spacing used

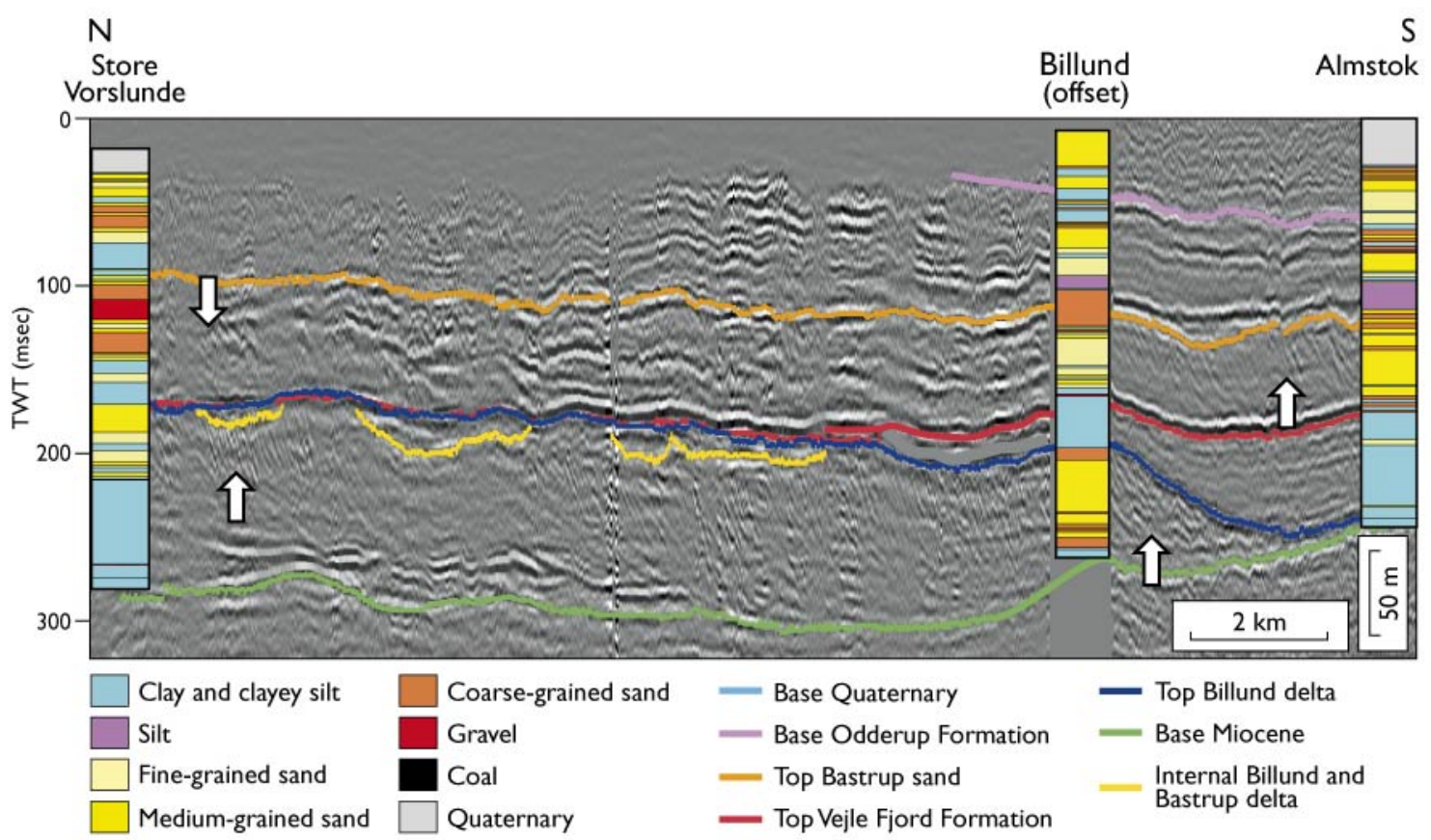

Fig. 3. Seismic section with boreholes from the Billund area illustrating two prograding deltaic sand-rich units (Billund sand and Bastrup sand). The grain size of the penetrated succession is indicated by different colours. Note that the parallel clinoformal seismic reflection pattern (arrows) always correlates with sand. Seismic data courtesy of COWI A/S and Rambøll A/S. 


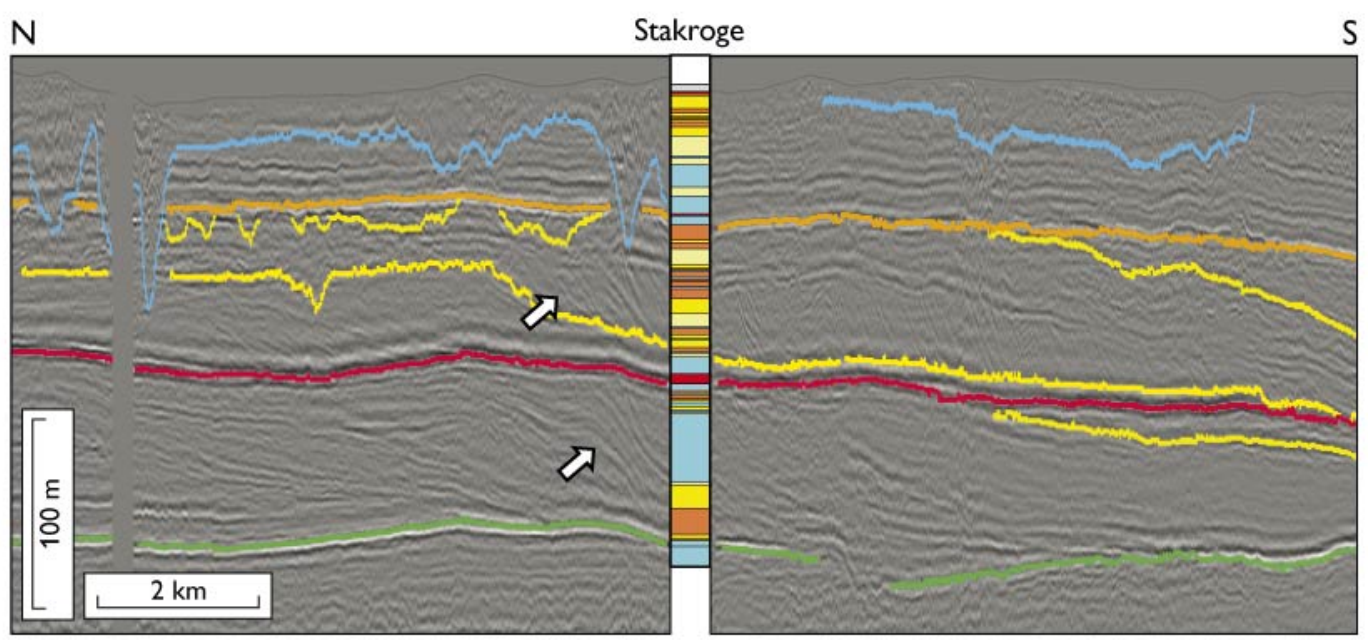

Fig. 4. Seismic section from Sønder Omme. Note the close relationship between the parallel clinoformal reflection pattern and the sand as indicated by the arrows. Note especially the lower delta where only the toe of the delta front has been penetrated by the Stakroge borehole. Seismic data courtesy of Rambøll A/S. See Fig. 3 for legend.

in 2000 to the current $200-220 \mathrm{~m}$ streamers with 96-102 channels and differential geophone spacings of 1.25, 2.5 and $5 \mathrm{~m}$ (Vangkilde-Pedersen et al. 2003, 2006). The differential geophone spacing along the streamers, with the shortest spacing close to the vibrator, has greatly improved the quality and resolution of the near-surface data. In the same period, both the vibrator sweeps and processing of the data have also been optimised. During the first couple of years a simple standard processing sequence was applied to the data, but in recent years the processing sequence has been significantly improved.

\section{Examples of Lower Miocene reservoir sand}

Delta front sand. Thick delta front sands occur in association with progradation into deep water that is normally associated with structurally confined areas. Delta lobes deposited during a relative sea-level fall are especially sand-rich. These deposits are characterised by a parallel clinoform reflection pattern (Figs 3,4) in which the dip of the clinoforms range from $7^{\circ}$ to $10^{\circ}$. The thickness of sand associated with this reflection pattern has never been recorded as less than $20 \mathrm{~m}$ and thicknesses of up to $50 \mathrm{~m}$ have been found at Billund (Fig. 3); the thickness may be more than $70 \mathrm{~m}$ within the Brande lobe, north of Billund. The grain size is commonly medium to coarse sand, but gravel may occur in connection with mass-flow deposits on the delta front or in association with channels and shoreface deposits in the upper part of the delta. Delta sand laid down during a sea-level fall is particularly clean and homogenous.

Fluvial point-bar sand. Delta deposits of the Lower Miocene Bastrup sand are often capped by fluvial sediments that have been protected during the succeeding transgression. The fluvial channels are expressed by a concave-up structure filled with a shingled seismic reflection pattern probably representing point-bar deposits (Fig. 5). From seismic and borehole data, the point-bar deposits comprise up to $20 \mathrm{~m}$ thick, fining-upwards successions composed of coarse- to finegrained sand that are commonly capped by coal.

Incised valley sand. Well-defined, large, concave-upward erosional surfaces are found especially in the proximal parts of the deltas. The infills of these features on the seismic lines are often characterised by a transparent seismic reflection pattern (Fig. 6). From outcrop and borehole data the valleys are known to be filled typically by coarse-grained sand and gravel that were deposited in braided river systems. The thickness and lateral distribution of the fill vary within the delta complexes.

\section{Future perspectives}

The application of seismic data in the search for aquifers in Denmark by recognition of different seismic reflection pat-

S N

Fig. 5. Seismic section showing shingled, seismic reflection pattern (arrow) within a channel structure. Similar structures have been found on 3D seismic data from Canada (Posamentier 2005) and represent lateral accretion of a point bar. Seismic data courtesy of COWI A/S 


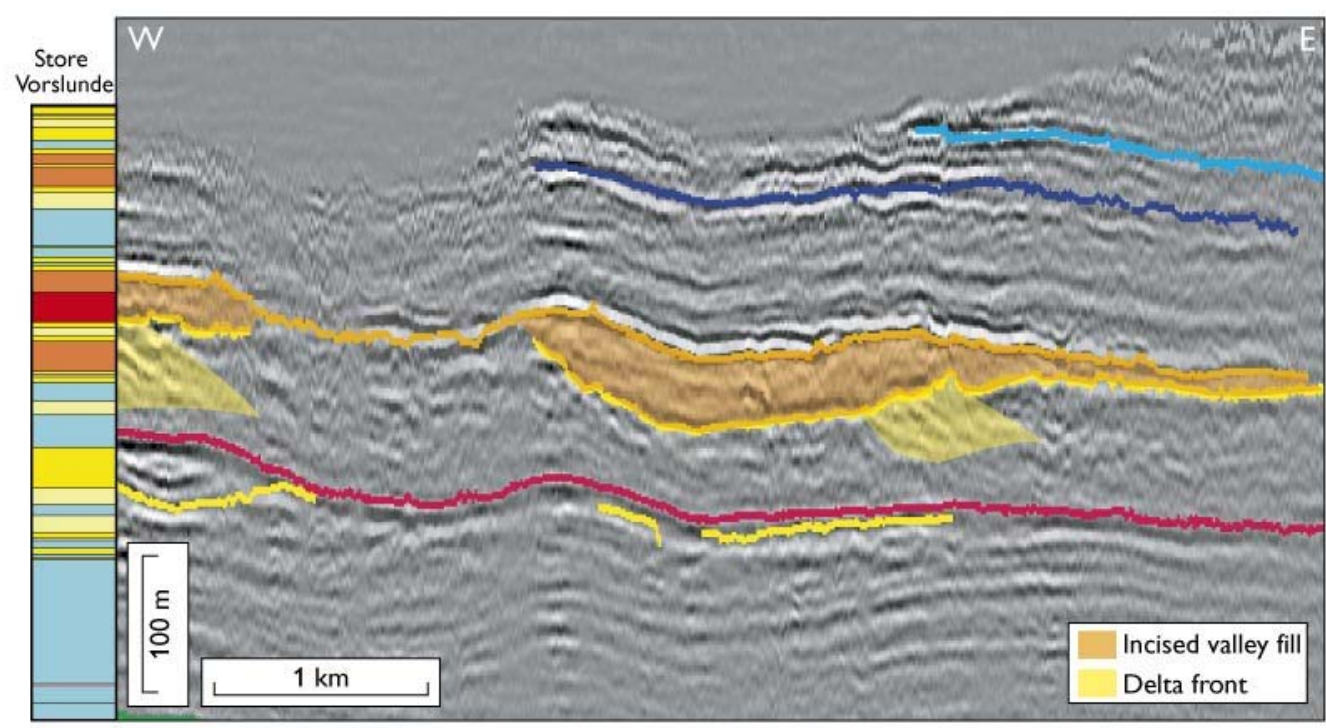

Fig. 6. Seismic section showing $2 \mathrm{~km}$ wide and $20 \mathrm{~m}$ deep erosional features on top of clinoforms interpreted as a fluvial valley fill. These features are often filled with coarse-grained sand or gravel deposits. Seismic data courtesy of COWI A/s.

terns and morphological features, e.g. the geometry of clinoforms, has proved to be useful in the prediction of sand-rich sediments in Miocene deposits. Sand-rich sediments in front of a delta complex are normally associated with clinoform reflection patterns. A shingled seismic reflection pattern within channels characterises sand-rich, point-bar deposits. Distinct erosional features, with a transparent reflection pattern, capping delta foresets commonly indicate fluvial sandrich sediments. A detailed mapping of the Miocene delta complexes and the construction of a three-dimensional model of delta lobes will be essential for developing future hydrogeological models.

Furthermore, the connection between the observed seismic facies and sand-rich environments may also be applied as a tool for prediction of Jurassic hydrocarbon reservoir sands in the North Sea area.

\section{Acknowledgements}

The Carlsberg Foundation and the counties of Vejle, Ringkøbing and Ribe are thanked for financial support of the study of the Miocene succession in Denmark.

\section{References}

Friis, H., Mikkelsen, J. \& Sandersen, P. 1998: Depositional environment of the Vejle Fjord Formation of the Upper Oligocene - Lower Miocene of Denmark: A back island/barrier-protected depositional complex. Sedimentary Geology 17, 221-244.
Posamentier, H.W. 2005: Application of 3D seismic visualization techniques for seismic stratigraphy, seismic geomorphology and depositional systems analysis: examples from fluvial to deep-marine depositional environments. In: Doré, A.G. \& Vining, B.A. (eds): Petroleum geology: North-West Europe and global perspectives - Proceedings of the 6th petroleum geology conference, 1563-1576. London: Geological Society.

Rasmussen, E.S. 2004: Stratigraphy and depositional evolution of the uppermost Oligocene - Miocene succession in western Denmark. Bulletin of the Geological Society of Denmark 51, 89-109.

Rasmussen, E.S. \& Dybkjær, K. 2005: Sequence stratigraphy of the Upper Oligocene - Lower Miocene of eastern Jylland, Denmark: role of structural relief and variable sediment supply in controlling sequence development. Sedimentology 52, 25-63.

van der Veen, M. \& Green, A.G. 1998: Landstreamer for shallow seismic data acquisition: valuation of gimbal-mounted geophones. Geophysics 63, 1408-1413.

van der Veen, M., Spitzer, R., Green, A.G. \& Wild, P. 2001: Design and application of a towed landstreamer for cost-effective $2 \mathrm{D}$ and pseudo3D shallow seismic data acquisition. Geophysics 66, 482-500.

Vangkilde-Pedersen, T., Skjellerup, P., Ringgaard, J. \& Jensen, J.F. 2003: Pulled array seismic (PAS) - a new method for shallow reflection seismic data acquisition. 65th EAGE Conference \& Exhibition, Stavanger, Norway, 2-5 June 2003. Extended abstracts, 201 only.

Vangkilde-Pedersen, T., Dahl, J.F. \& Ringgaard, J. 2006: Five years of experience with landstreamer vibroseis and comparison with conventional seismic data acquisition. Proceedings of the 19th Annual SAGEEP Symposium on the Application of Geophysics to Engineering and Environmental Problems, Seattle, USA, 1086-1093.

Ziegler, P. 1990: Geological atlas of western and central Europe, 2nd edition, 239 pp, Mijdrecht: Shell International Petroleum.

\section{Authors' address}

Geological Survey of Denmark and Greenland, Øster Voldgade 10, DK-1350 Copenhagen K, Denmark. E-mail: esr@geus.dk 